
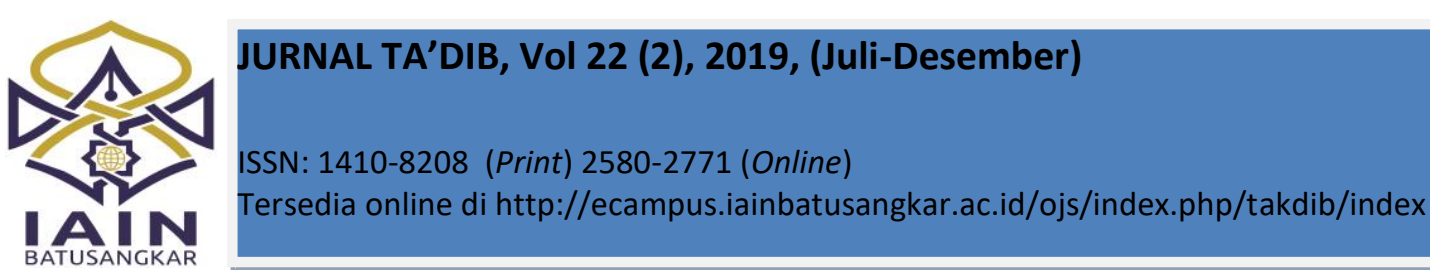

\title{
Optimalisasi Tes Prestasi Buatan Guru Mata Pelajaran IPS SD untuk Evaluasi Pembelajaran yang Presisi
}

\author{
Ayu Rahma Nengsi*) \\ STAIN Gajah Putih Takengon Aceh \\ E-mail: rahmanengsiayu@gmail.com

\section{Gusnita Efrina} \\ Universitas Nahdatul Ulama Sumatera \\ Barat \\ E-mail: gusnitaefrina@gmail.com
}

\begin{abstract}
The research goal is to develop an accurate learning evaluation instrument in Social science (IPS) subject in elementary school. The method used is Research and Development, following the 4 main steps of the Richey RDPE model, namely: research, design, production and evaluation. Field trials were carried out 2 times, with the number of respondents increasing each stage. Analysis of item characteristics uses classical test theory. The results of the development are in the form of achievement tests for Social science subjects at the fifth grade of elementary school, consisting of 35 multiple choice items and 5 essay items. The test was developed by following the standards for writing a proper test, all procedures taken have been approved by experts from a qualitative perspective. Item analysis is performed for multiple choice tests with $94.3 \%$ of questions have moderate difficulty level, the range of index values is 0.53-0.67. 80\% of the items have good differentiation, the average index value is 0.30-0.50. Optimization of teacher-made achievement tests produces more qualified test kits in performing measurement functions, as evidenced by the scores obtained by students which accurately describe their real abilities during the learning process.
\end{abstract}

*) Corresponding Author

Keywords : Optimalization, Teacher-Made Achievement Tests, Item Characteristics Analysis

\section{PENDAHULUAN}

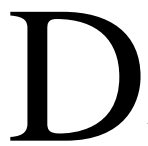
alam proses pendidikan akan selalu ada situasi yang memerlukan pengambilan keputusan pendidikan, salah satunya yaitu evaluasi hasil belajar, setelah peserta didik melewati serangkaian proses. Kegiatan evaluasi dalam pembelajaran dilakukan dengan tujuan, melihat perkembangan siswa baik itu kemajuan maupun kelemahan yang patut dibenahi. Untuk itu diperlukan kegiatan pengukuran hasil belajar, menggunakan sebuah instrumen atau alat, secara lebih spesifik diperoleh dari tes prestasi belajar. Instrumen yang baik akan memberikan informasi yang tepat, sehingga akan mempengaruhi keputusan yang diambil oleh pihak sekolah. Azwar (2010) menegaskan, benar dan dapat dipercayanya informasi yang diperoleh, tergantung sejauh mana tes yang digunakan memenuhi kriteria sebagai tes prestasi yang layak.

Tes prestasi yang layak akan melakukan fungsinya dengan baik, bila dikembangkan melalui prosedur pengembangan tes yang benar (Azwar, 2010). Secara umum tes yang baik memiliki syarat-syarat antara lain: (1) memenuhi tuntutan validitas artinya hanya mengukur satu aspek saja dan (2) memenuhi tuntutan reliabilitas yaitu handal dalam pengukuran. Kehandalan ini meliputi ketepatan hasil pengukuran dan keajegan hasil pengukuran (Pugh et al., 2016)

Era otonomi saat ini, mengharuskan pemerintah daerah bertanggung jawab penuh atas pelaksanaan ujian akhir semester beserta kualitasnya. Soal UTS dan UAS dikembangkan oleh guru yang tergabung dalam kelompok kerja guru, yang mempunyai wilayah kerja pada setiap 
kabupaten/kota (Suyata, Mardapi \& Kartowagiran, 2010). Sementara tes buatan guru memiliki banyak kelemahan. Berbagai penelitian menjelaskan lemahnya kemampuan daya ukur dari tes prestasi buatan guru. Beberapa kelemahan tersebut diantaranya: konstruksi soal yang kurang tepat menurut kaidah penulisan soal, naskah tes yang tidak didesain secara baik, lebih merupakan duplikasi dari soal-soal terdahulu, tidak ada uji coba empiris, review maupun revisi (Zamsir, 2012). Selain itu tidak diketahui karakteristik butir dari instrumen tersebut, sehingga sulit untuk diputuskan apakah tes tersebut layak, atau memenuhi syarat digunakan sebagai alat dasar penilaian (Anto and Mardapi, 2013)

Pra survei terhadap tes prestasi buatan guru dibeberapa SD Negeri Kecamatan
Lubuk Alung, Kabupaten Padang Pariaman, soal ujian akhir semester dan tengah semester yang dibuat terdiri atas pilihan ganda dan essay. Wawancara dengan 10 orang guru dalam kegiatan KKG yang diikuti dapat disimpulkan bahwa banyak guru yang tidak memiliki pengetahuan yang memadai dalam mengembangkan instrumen tes. Suranto, Muhyadi \& Mardapi (2014) menyatakan bahwa hampir semua guru yang terlibat dalam penyusunan tes prestasi, bahkan tidak mendapatkan pelatihan, ataupun bimbingan teknis dalam perancangan naskah soal ujian semester. Sehingga agaknya tes yang disusun mengandung semua kelemahan seperti yang dipaparkan diatas. Beberapa kelemahan tes prestasi buatan guru yang ditemukan saat observasi lapangan dapat dilihat pada tabel 1 .

Tabel. 1 Kelemahan Tes Prestasi Buatan Guru

\begin{tabular}{|c|c|}
\hline No & Kelemahan \\
\hline 1 & $\begin{array}{l}\text { Tes yang dikembangkan tidak mengikuti prosedur penyusunan tes yang layak lantaran guru } \\
\text { belum memiliki keterampilan memadai dalam merancang tes }\end{array}$ \\
\hline 2 & $\begin{array}{l}\text { Tes yang dikembangkan tidak melewati tahapan uji coba sehingga tidak diketahui secara } \\
\text { empiris karakteristik setiap butirnya }\end{array}$ \\
\hline 3 & $\begin{array}{l}\text { Tes yang dikembangkan tidak menggunakan kisi-kisi sebagai panduan penulisan, sehingga } \\
\text { soal yang dibuat berkemungkinan belum komprehensif mewakili semua materi yang ingin } \\
\text { diuji }\end{array}$ \\
\hline 4 & $\begin{array}{l}\text { Tidak diketahui secara pasti apakah tes yang dikembangkan sudah valid dari segi konten } \\
\text { maupun konstruk mengingat tIdak mendapat validasi dari ahli }\end{array}$ \\
\hline 5 & $\begin{array}{l}\text { Ditemukan beberapa guru menduplikasi soal-soal ujian semester yang lama secara acak } \\
\text { untuk dijadikan soal ujian pada semester berjalan }\end{array}$ \\
\hline 6 & Tidak jelas tingkatan kognitif taxonomy Bloom yang ingin diukur. \\
\hline
\end{tabular}

Sumber: data primer lapangan

Para guru cenderung beranggapan kegiatan kontruksi tes dianggap selesai saat jumlah soal yang ditulis dirasa cukup. Soal tersebut bahkan tidak diuji cobakan, dianalisis maupun direvisi. Tidak diketahui apakah tes telah tersusun atas butir yang baik, valid dan reliabel. Kemungkinan terdapatnya butir atau item tes yang cacat sangat tinggi, pada akhirnya akan sangat merugikan siswa (Wiliam et al., 2010) Sementara itu tes prestasi yang baik penting untuk memperhatikan tingkat kesukaran, daya pembeda dan keberfungsian distraktor (Arifin, 2017) serta terpenuhinya tuntutan validitas dan reliabilitas (Hill et al., 2011)
Penelitian tentang kualitas tes buatan guru cukup banyak dilakukan, tetapi hanya sebatas survei guna mengetahui karakteristik butirnya saja. Tidak ada usaha lanjutan untuk memperbaiki kualitas dari produk tes prestasi buatan guru tersebut. Penting sekali ada penelitian yang berupaya memperbaiki serta meningkatkan kualitas dari produk tes prestasi yang telah ada sebelumnya, mengingat kemungkinan adanya duplikasi soal terdahulu oleh guru sangatlah tinggi. Informasi yang paling besar sumbangannya dalam mengambil keputusan pendidikan, diperoleh dari kegiatan pengukuran melalui tes prestasi. Oleh karena itu peneliti 
melakukan R \& D yaitu: Optimalisasi Tes Prestasi Buatan Guru Mata Pelajaran IPS SD untuk evaluasi pembelajaran yang presisi.

Tekait dengan permasalahan yang diuraikan, penting sekali ada penelitian dan usaha lanjutan untuk memperbaiki, dan meningkatkan mutu pengukuran dari instrumen tes yang dirancang oleh guru. Penelitian ini dirumuskan sebagai berikut: a) bagaimanakah content validity dari tes prestasi yang dioptimalkan? b) bagaimanakah kualitas butir (taraf sukar dan daya beda) dari tes prestasi yang dioptimalkan?. Secara khusus penelitian ini bertujuan untuk: a) Meningkatkan content validity dari tes yang dioptimalkan b) melakukan uji coba empiris untuk menganalisis kualitas butir (taraf sukar, daya beda) c) Merevisi butir tes berdasarkan uji expert dan analisis butir, guna meningkatkan daya ukur dari tes prestasi tersebut. Penelitian pengembangan ini diharapkan dapat menghasilkan instrumen tes yang memenuhi kriteria sebagai tes prestasi yang layak. Dengan spesifikasi: tes prestasi tervalidasi oleh expert, memiliki kualitas butir yang baik, valid dalam melakukan pengukuran, sehingga dapat memberikan informasi yang tepat dalam pengambilan keputusan pendidikan.

\section{METODE PENELITIAN}

Tahapan penelitian ini adalah peneliti melakukan pra survei lapangan dan studi literatur untuk mengidentifikasi dan merumuskan masalah yang urgen dalam pendidikan. Menjelang ujian semester, kelompok kerja guru (KKG) pada setiap wilayah di Kabupaten Padang Pariaman merancang tes untuk ujian sekolah. Tes yang telah dikembangkan tersebut langsung dipakai tanpa adanya uji coba empiris maupun analisis kualitas butir. Ini berarti tidak diketahuinya secara empiris kualitas butir dari soal yang digunakan. Apakah tes tersebut telah tersusun atas butir yang baik, tidak dapat diketahui dengan jelas. Perangkat tes buatan guru inilah yang digunakan sebagai dasar untuk mengembangkan tes prestasi belajar, yang sesuai dengan standar prosedur penulisan tes yang benar.

Penelitian ini merupakan penelitian Research dan Development level 3 yaitu meneliti dan mengembangkan produk yang telah ada. Pengembangkan instrumen tes prestasi, berpedoman pada model pengembangan dari Richey RDPE yaitu: research, design, production dan evaluation. Tes UAS IPS buatan guru dikumpulkan dari sekolah, untuk dijadikan dasar dalam mengembangkan instrumen tes prestasi yang baru. Selanjutnya tes prestasi yang telah dirancang, dianalisis secara kualitatif oleh ahli, untuk mendapatkan masukan, demi meningkatkan validitas isi dari tes. Tes direvisi sesuai saran perbaikan yang di anjurkan.

Perangkat tes yang telah mendapatkan persetujuan ahli, dilakukan uji coba lapangan. Guna untuk mengetahui respon siswa, demi kebutuhan analisis kualitas butir tes secara empiris. Uji coba instrumen dilakukan sebanyak 2 kali dengan jumlah responden bertambah untuk setiap tahapannya. Jumlah responden pada uji coba pertama terbatas pada 40 orang siswa kelas V SD. Data hasil uji coba pertama dianalisis untuk mengetahui estimasi tingkat kesulitan butir soal dan daya pembeda. Soal dengan kategori buruk akan direvisi atau dibuang bila estimasi nilai indeksnya terlalu buruk. Perangkat tes disusun kembali untuk dilakukan uji coba lapangan kedua pada responden siswa yang lebih besar, berjumlah 100 orang dengan tetap mengikuti setiap tahapanan yang sama seperti sebelumnya.

Untuk tes essay analisis dilakukan menggunakan pendekatan kualitatif, yang difokuskan pada pengujian conten validity dan prosedur penskoran. Sedangkan tes pilihan ganda selain analisis cotent validity, juga dilakukan analisis butir tes secara statistik menggunakan teori tes klasik. Hasil analisis tes akan dijadikan rujukan untuk melakukan revisi. Butir tes yang layak yang memenuhi syarat tes yang berkualitas baik akan di pakai. Butir tes yang tidak layak berdasarkan analisis statistik akan diperbaiki atau bila terlalu buruk akan dibuang. Berikut 
tahapan penelitian ditampilkan dalam diagram alir.

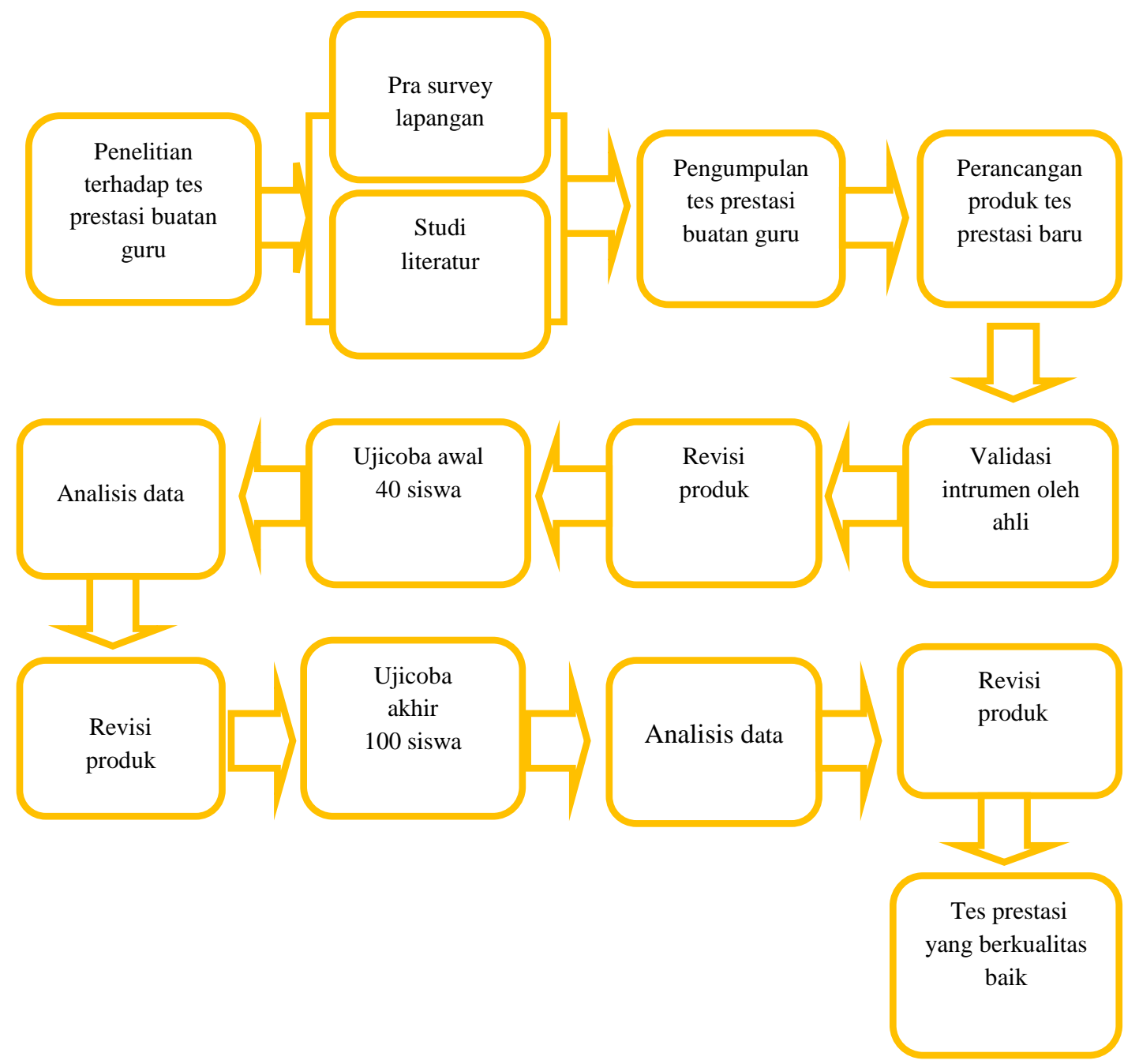

Gambar. 1. Diagram alir penelitian 


\section{HASIL DAN PEMBAHASAN}

\section{Tes Prestasi Buatan Guru Sebelum Proses Optimalisasi}

Dokumentasi tes prestasi buatan guru di sekolah yang telah dikumpulkan, dikonsultasikan pada ahli. Secara umum penilaian ahli terhadap tes dapat disimpulkan, terdapat banyak kekurangan pada perangkat tes tersebut diantaranya: ditemukan beberapa soal yang masih menggunakan kata "kecuali" sedangkan soal dengan pernyataan negatif sangat dilarang karena bisa membingungkan siswa. Redaksi bahasa yang digunakan dalam soal, maupun pilihan jawaban yang tersedia masih belum tepat, karena beberapa soal dirasa ambigu dan tidak jelas hal yang ingin ditanyakan. Selain itu pengecoh dari options jawaban yang disediakan belum berfungsi dengan baik, karena sangat mudah untuk ditebak jawaban dari pertanyaan, dan lain sebagainya. Begitu banyak kekurangan dalam soal yang dibuat guru, secara umum tes tersebut belum memiliki validitas isi yang baik.

Analisis karakteristik butir yang
dilakukan pada tes tersebut,
menginformasikan dari 35 butir pilihan ganda yang ada, hanya 15 yang memenuhi kriteria sebagai tes yang baik yang memiliki taraf sukar sedang, 13 diantaranya memiliki daya beda yang bagus. Sedangkan 20 sisanya berkategori buruk. Analisis validitas butir juga dilakukan pada tes, hasilnya hanya 11 butir yang valid dari 35 butir yang dianalisis, dan memiliki indeks relibilitas yang sangat buruk yaitu 0.47. Secara keseluruhan tes buatan guru ini belum bisa memberikan informasi yang benar bila digunakan sebagai alat ukur hasil belajar siswa. Sesuai dengan pandangan (Azwar, 2010) bahwa hasil pengukuran, dijadikan dasar dalam mengambil keputusan. Bila informasi yang dijadikan rujukan dalam mengevaluasi siswa tidak benar, maka keputusan pendidikan yang diambil menjadi tidak tepat sasaran.

\section{Tes Prestasi Setelah Optimalisasi}

Empat tahapan dilakukan dalam kegiatan proses optimalisasi tes prestasi buatan guru, mengikuti model pengembangan oleh Richey RDPE, dengan hasil sebagai berikut:

\section{Tahap research}

Pada tahap ini, dilakukan kegiatan observasi lapangan. Temuan lapangan menunjukkan instrumen evaluasi yang cenderung digunakan, untuk menilai hasil belajar IPS siswa adalah soal bentuk pilihan ganda dan essay. Kedua jenis tes ini selalu dipakai oleh guru dalam UTS maupun UAS, dengan rata-rata jumlah soal yaitu 40 butir. bentuk soal pilihan ganda mendapatkan porsi lebih besar dari pada soal essay. Rata- rata dari 40 buah butir tes yang ada, 30-35 butir diantaranya merupakan soal bentuk pilihan ganda dan sisanya adalah tes essay yang terdiri atas isian maupun essay terstruktur.

Hasil wawancara bebas dengan 10 orang guru, yang merupakan anggota tim penyusunan soal ujian semester di tingkatan sekolah dasar, disimpulkan kalau tes prestasi yang dirancang, belum mengikuti prosedur penulisan instrumen tes yang layak. Hal ini berarti informasi yang diberikan oleh hasil pengukuran tes tersebut belum valid. (Azwar, 2010) menjelaskan, benar dan dapat dipercayanya informasi yang diperoleh, tergantung pada sejauh mana tes yang digunakan memenuhi kriteria sebagai tes prestasi yang layak. Tes tersebut akan melakukan fungsinya dengan baik, bila dikembangkan sesuai dengan prosedur penyusunan tes yang benar.

\section{Tahap Design}

Pada tahap ini dilakukan kegiatan merumuskan tujuan tes yaitu untuk evaluasi hasil belajar, memilih jenis soal yang akan di gunakan, dan cara penilaian. Ranah kognitif yang diukur dibatasi pada 3 tingkatan dalam taxonomy Bloom yaitu ranah pengetahuan, pemahaman dan aplikasi, mengingat tes diperuntukan untuk mengukur kognitif siswa tingkatan sekolah dasar. Jenis soal yang dirancang yaitu tes pilihan ganda dan tes essay dengan jumlah 40 butir. Dengan 
proporsi 35 butir bentuk pilihan ganda dan 5 (lima) butir soal essay. Untuk siswa SD jumlah pilihan jawaban pada tes pilihan ganda berjumlah 4 buah. Soal yang dibuat ditujukan untuk mengukur ranah kognitif, dengan tingkatan taxonomy Bloom yang diukur yaitu aspek pengetahuan (C1), pemahaman (C2) dan aplikasi (C3).

\section{Tahap Production}

Kegiatan pada tahap produksi yaitu merancang instrumen tes prestasi mengikuti prosedur penyusunan tes yang layak. Menyusun tabel blue print atau kisi-kisi tes, sebagai panduan agar butir tes yang dibuat relevan dengan indikator dalam silabus, serta tes yang disusun secara komprehensif mewakili semua materi yang diajarkan. Kisikisi juga dibuat bertujuan untuk meningkatkan content validity dari tes.

\section{Tahap Evaluation}

Tahap evaluasi merupakan tahap penilaian terhadap instrumen tes yang dibuat. Evaluasi dilakukan pada dua aspek, yaitu pertama secara kualitatif melalui validasi ahli dan kedua evaluasi secara kuantitatif dengan analisis butir tes. Data karakteristik butir diperoleh dari hasil uji coba lapangan. Bila tes yang dikembangkan tersebut bertujuan untuk menginformasikan hasil belajar siswa, setelah melewati serangkaian kegiatan pembelajaran, maka kegiatan uji coba dan analisis butir hendaknya menjadi suatu keharusan yang patut dilakukan. Studi tentang pengembangan instrumen menjelaskan, analisis butir tes dapat menentukan kualitas informasi yang diberikan oleh tes tersebut (Adedoyin and Mokobi, 2013)

\section{a) Evaluasi secara kualitatif (Content validity)}

Untuk tes pilihan ganda dan essay optimasi content validity dilakukan melalui diskusi dengan dua orang pakar, yaitu ahli mata pelajaran IPS SD dan ahli Evaluasi Pendidikan. Validitas isi tes ditingkatkan dengan menilai kesesuaian antara silabus, materi, indikator dengan butir tes yang dirancang apakah telah komprehensif mencakup semua materi yang dipelajari.
Hasil evaluasi ahli menganjurkan perbaikan pada perangkat tes khususnya pada beberapa substansi berikut: 1) domain taxonomy Bloom yang diukur dianjurkan pada tiga aspek yaitu: pengetahuan, pemahaman dan aplikasi, 2) perhatian lebih pada redaksi bahasa yang dirasa masih ambigu dan membingungkan peserta tes saat membacanya, 3) soal yang dibuat harus mencakup semua materi yang hendak diukur secara komprehensif. Terlihat ada beberapa indikator tidak ada pada soal yang dibuat dan beberapa indikator lainya memiliki lebih dari dua buah pertanyaan, artinya semua materi belum terjabar dalam item, 4) aspek struktur tes dianjurkan porsi soal bentuk pilihan ganda sebaiknya $80 \%$ dari total soal 5) pertanyaan yang bernada negatif seperti pertanyaan "kecuali" hendaknya dihindari, 6) aspek tata bahasa dan EBI (Ejaan Bahasa Indonesia) dalam penulisan tes, kekeliruan dalam EBI juga akan merugikan siswa dalam memahami soal 7) soal dengan ilustrasi visualisasi, berupa gambar atau peta sangat baik untuk mengembangkan daya nalar siswa dalam berfikir. Hal ini bisa meningkatkan ketertarikan siswa dalam menjawab soal, serta mengurangi tingkat kebosanan selama ujian berlangsung.

Mengembangkan item tes untuk evaluasi hasil belajar memang tidaklah mudah. Diperlukan keahlian dalam menyusun butir tes yang sesuai dengan materi yang telah dipelajari, sehingga item tes yang ditulis tersusun secara benar, sesuai dengan domain kognitif yang ingin diukur. Sebuah hasil studi menjelaskan bahwa instrumen tes yang baik hendaknya meliputi semua materi yang di pelajari secara komprehensif (Gierl, Lai \& Turner, 2012) Hal ini bermakna bahwa tes yang baik hendaknya menguji secara komprehensif semua materi yang diajarkan dengan mengembangkan tes yang taat mengikuti prosedur yang layak.

\section{b) Analisis Karakteristik Butir (Tingkat} Kesukaran Dan Indeks Deskriminasi)

Uji coba lapangan dilakukan untuk mendapatkan respon dari siswa terhadap soal yang dibuat. Gunanya mendapatkan data 
empiris dari lapangan untuk mengetahui tingkat kesulitan butir soal dan daya pembeda dari setiap item yang dibuat (Odukoya et al., 2018)

Uji coba dilakukan sebanyak 2 tahap. Tahap pertama dilakukan pada sampel yang kecil, yaitu 40 siswa dan uji coba tahap kedua dilakukan pada sampel yang lebih luas yaitu 100 orang siswa yang dipilih secara acak. Proses uji coba dilakukan dengan bantuan guru kelas, dengan terlebih dahulu mensepakati hari, kapan kegiatan uji coba dilakukan, sehingga guru dapat meminta siswanya untuk mempersiapkan diri. Bantuan guru kelas dalam kegiatan uji coba sangat bermanfaat, agar siswa serius dalam pengerjaan tes, sehingga data yang diperoleh tidak bias.

Data hasil uji coba pertama dan kedua dibutuhkan untuk analisis butir, guna mengetahui karakteristik dari setiap butir tes yang dibuat. Analisis menggunakan teori tes klasik, karena lebih familiar dan dikenal cukup baik oleh guru di sekolah. Butir tes diolah menggunakan MS Exel agar dapat dimanfaatkan oleh guru pada kegiatan analisis tes berikutnya. Analisis karakteristik butir tes diperuntukan untuk tes pilihan ganda untuk mengestimasi tingkat kesulitan butir dan indeks deskriminasi butir.

Hasil analisis karakteristik butir menginformasikan, dari 35 butir tes pilihan ganda yang diperiksa, secara keseluruhan memiliki tingkat kesulitan butir yang baik. 94.3\% butir diantaranya memiliki tingkat kesulitan soal sedang, dengan rentang nilai indeks $0.30-0.70$ dan $5.7 \%$ butir tes memiliki tingkat kesulitan soal mudah dengan nilai indek 0.71-1.00 serta tidak ada soal yang tergolong sulit.

Estimasi empiris terhadap indeks kesulitan butir menunjukkan, secara umum perangkat tes yang dibuat telah tersusun atas butir yang baik. Selaras dengan riset Dibattista \& Kurzawa (2011) bahwa bila jumlah butir tes yang indeks kesulitan butirnya, berada di bawah 0.30 (soal sulit), atau diatas 0.90 (soal mudah), memiliki kemungkinan yang kecil, dalam melakukan deskriminasi yang memuaskan, dibanding butir tes dengan indeks kesulitan pada rentangan 0.30-0.70 (soal sedang)

Dalam analisis karkateristik butir, estimasi terhadap deskriminasi butir mutlak dilakukan untuk melihat kemampuan butir tes dalam membedakan kemampuan antar siswa. Hasil analisis menginformasikan, dari 35 butir tes pilihan ganda yang diuji cobakan $80 \%$ diantaranya memiliki deskriminasi yang baik dengan kisaran nilai indeks deskriminasi berada pada rentangan 0.300.39 , dan $2.9 \%$ butir tes memiliki deskriminasi yang sangat baik dengan nilai indeks berada pada rentangan $>0.4$. Sedangkan ada 6 butir tes atau $17.1 \%$ yang memiliki kekuatan deskriminasi yang rendah.

Banyak studi menemukan kecenderungan butir tes yang dirancang, memiliki kemampuan deskriminasi yang rendah, namun butir tes dengan kemampuan deskriminasi yang rendah perlu perbaikan agar hasil pengukuran dari tes tersebut terpercaya. Dijelaskan oleh Pugh et al. (2016) bahwa keandalan dari tes pilihan ganda sangat tergantung pada kekuatan dari deskriminatif butir tes yang menyusunnya. Artinya tes yang memiliki kemampuan deskriminasi yang baik akan mampu memberikan hasil pengukuran yang tepat. Disisi lain Azwar (2010) menjelaskan tidak ada ketentuan yang bersifat baku, berapa tingkat taraf sukar dan daya beda yang dianggap ideal. Artinya semuanya tergantung pada pengguna dan tujuan tes itu sendiri. Jika tes ditujukan untuk kebutuhan penilaian hasil belajar siswa dalam kurun tertentu, maka estimasi karakteristik butir tes yang dikembangkan ini telah sesuai dengan ketentuan dan kebutuhan. Karena lebih dari $80 \%$ butir yang dirancang memiliki nilai indeks kesulitan soal yang sedang dan kemampuan deskriminasi butir yang baik.

Dengan kondisi setiap daerah yang sekarang merupakan wilayah otonom, berarti pemerintah pusat tidak lagi menyediakan instrumen tes prestasi belajar yang baku, daerahlah yang harus mengambil alih tugas tersebut. Sesuai dengan temuan Yew, Dawood \& Narayansany (2015) setiap 
institusi pendidikan hendaknya menyediakan instrumen sendiri, yang dirasa cocok untuk penilaian. Pandangan ini selaras dengan fakta lapangan, bahwa penggunaan tes pilihan ganda maupun essay sangat tinggi ditingkat sekolah dasar karena dipandang sesuai dengan kebutuhan penilaian. Dapat dipahami kebutuhan akan instrumen yang berkualitas merupakan hal yang urgen dalam proses pendidikan. Apakah proses pembelajaran yang terjadi telah mencapai tujuan yang diharapkan?, apakah perlu perbaikan atau pengayaan?, semua tergantung pada hasil penilaian yang dilakukan.

Odukoya et al. (2018) menjelaskan tepat atau tidaknya informasi yang diperoleh dari hasil pengukuran, semua dipengaruhi oleh instrumen yang digunakan. Hal ini berarti Instrumen yang baik akan memberikan informasi yang benar, dan instrumen yang buruk akan memberikan hasil yang sebaliknya. Informasi yang benar sangat penting dalam proses evaluasi, sehingga keputusan yang diambil oleh pemangku kebijakan dalam pendidikan menjadi tepat sasaran.

Azwar (2010) mengatakan bahwa instrumen tes dapat dikatakan layak dalam melakukan fungsi pengukuran bila dirancang sesuai dengan prosedur yang benar. Optimasi tes prestasi mata pelajaran IPS ini telah mendapatkan persetujuan dari ahli, baik dari segi validasi secara kualitatif maupun analisis secara kuantitatif. Semua prosedur yang dilalui dari awal perancangan hingga akhir mengikuti prosedur pengembangan tes dengan standar baku.

\section{Efek Optimalisasi Tes terhadap Evaluasi Hasil Belajar}

Mengingat minimnya kompetensi guru dalam merancang alat evaluasi hasil belajar, bukan hal yang aneh kalau instrumen yang dikembangkan juga belum tentu baik dalam melakukan fungsi pengukuran. Dengan adanya usaha mengoptimalkan daya ukur dari tes prestasi yang telah ada, dapat membantu pihak sekolah khususnya guru dalam mengukur hasil belajar siswa secara tepat dan benar. Walaupun guru sebagai evaluator terdepan dalam melakukan evaluasi hasil belajar siswa. Mereka yang paling memahami kekurangan dan kelebihan dari setiap siswa, lantaran berhadapan langsung dengan mereka. Namun untuk mendapatkan hasil pengukuran yang tepat, mutlak diperlukan sebuah instrumen yang dapat bekerja dengan benar dalam melakukan fungsinya.

Setelah melewati serangkaian tahapan dan proses uji coba empiris serta revisi butir, tes yang dikembangkan ini mampu memberikan hasil yang benar dalam melakukan fungsi pengukuran. Terbukti dari hasil penskoran nilai siswa pada kegiatan uji coba tahap kedua. Dimana hasil belajar siswa yang diperoleh dari beberapa sekolah uji coba, menunjukkan terdapatnya keselarasan antara nilai yang mereka peroleh dengan kondisi real siswa tersebut dalam kelas. Hal ini diketahui dengan menunjukkan nilai tersebut pada guru kelas yang bersangkutan. Guna memastikan apakah nilai yang diperoleh tersebut, sesuai dengan kemampuan belajar mereka selama ini, karena gurulah yang paling tau akan kemampuan setiap muridnya.

Dari 6 sekolah tempat uji coba kedua, semua sekolah membenarkan secara umum nilai yang diperoleh oleh siswa tersebut, secara tepat menggambarkan kemampuan real mereka. Namun ada beberapa siswa yang justru membuat heran para guru, beberapa murid yang dikenal memiliki kemampuan sedang berdasarkan pengukuran tes buatan guru. Justru pada tes yang dikembangkan ini memberikan hasil yang lebih baik dari biasanya, bahkan setara dengan siswa yang tergolong top 5 besar. Ini menunjukkan tes yang selama ini digunakan belum tepat dalam mengestimasi kemampuan real setiap siswa. Sebuah studi menegaskan bahwa keberadaan butir tes yang cacat atau tidak baik dalam perangkat tes akan sangat merugikan siswa yang lebih baik (Oche, 2012) Semua temuan lapangan ini cukup untuk menjelaskan bahwa tes yang dirancang dengan mengikuti prosedur yang layak, dapat memberikan hasil pengukuran 
yang tepat dan sesuai dengan kondisi real kemampuan kognitif siswa.

\section{KESIMPULAN DAN REKOMENDASI Kesimpulan}

Hasil Optimalisasi tes prestasi buatan guru mata pelajaran IPS SD dapat disimpulkan sebagai berikut:

1. Hasil evaluasi kualitatif

Evaluasi instrumen tes secara kualitatif dilakukan melalui validasi ahli. Evaluasi pakar berpijak pada perbaikan validitas isi dari tes, yaitu tes yang ditulis telah tersusun atas butir yang komprehensif, mewakili semua materi yang diajarkan dalam kurun waktu tertentu. Butir soal yang ditulis juga relevan dengan indikator dalam silabus. Tes prestasi ini dikategorikan sebagai tes yang layak, telah mengukur konstruk pengetahuan, pemahaman dan aplikasi pada kognitif siswa. Semua prosedur yang ditempuh mendapatkan pengawasan dan persetujuan dari ahli evaluasi dan ahli IPS.

2. Hasil analisis karakterisitik butir tes

Optimalisasi tes juga dilakukan secara kuantitatif, untuk mengetahui estimasi tingkat kesulitan butir dan kemampuan deskriminasi butir, sehingga dapat diketahui sekumpulan butir tersebut baik atau tidak. Hasil analisis butir menginformasikan bahwa 35 butir soal bentuk pilihan ganda yang diujikan lebih dari $80 \%$ butir yang dibuat memiliki tingkat kesulitan soal yang sedang yaitu berada pada nilai indeks 0.30-0.70. Sedangkan estimasi daya deskriminasi butir juga hampir $80 \%$ butir diantaranya memiliki kemampuan daya pembeda yang baik, yaitu berada pada nilai indeks 0.30-0.39. Walaupun ada beberapa butir tes yang tergolong memiliki deskriminasi yang tidak memuaskan. Secara keseluruhan tes prestasi yang dioptimalkan ini telah memenuhi syarat sebagai tes prestasi yang layak.

\section{Rekomendasi}

Institusi pendidikan dan semua pelaku pendidikan khususnya guru, selaku evaluator terdepan sebaiknya menyupayakan peningkatkan kualitas instrumen tes yang dibuat. Penting sekali mengembangkan instrumen dengan prosedur yang benar.
Mendapatkan validasi oleh ahli demi kesesuaian antara item yang ditulis dengan materi yang diajarkan dan analisis item hendaknya menjadi suatu kebutuhan yang patut dilakukan, dalam rangka mengetahui karakteristik setiap butir tes yang ditulis. Semuanya kegiatan tersebut akan menghasilkan tes yang berkualitas, sehingga hasil pengukuran dari tes tersebut dapat dipercaya dalam evaluasi pendidikan.

Mengingat uji coba lapangan yang dilakukan dalam kegiatan penelitian ini terbatas pada subjek uji coba yang tidak begitu luas yaitu 100 orang siswa, maka sangat baik bila subjek uji coba siswa lebih besar lagi. Hal ini agar informasi yang diperoleh dari analisis data lapangan lebih valid. Selain itu analisis karakteristik butir dilakukan menggunakan teori tes klasik. Jadi informasi tingkat kesulitan butir dan deskriminasi tes yang diberikan dipengaruhi oleh karakteritik siswa.

\section{REFERENSI}

Adedoyin, O. O. and Mokobi, T. (2013) 'Uing Irt Psycoetric Anlysis In Examining The Quality Of Junior Certificate Mathematics Multiple Choice Examination Test Items', 3(4), pp. 992-1011.

Anto, S. and Mardapi, ) Djemari (2013) 'Jurnal Penelitian dan Evaluasi Pendidikan', Jurnal Penelitian dan Evaluasi Pendidikan, (02), pp. 369388.

Arifin, Z. (2017) 'Kriteria Instrumen dalam suatu Penelitian', 2(1), pp. 28-36.

Azwar, S. (2010) Tes Prestasi fungsi dan pengembangan pengukuran prestasi belajar. II. yogyakarta: Ppustaka Pelajar.

Dibattista, D. and Kurzawa, L. (2011) 'Examination of the Quality of Multiple-choice Items on Classroom Tests Examination of the Quality of Multiple-choice Items on Classroom Tests', 2(2).

Gierl, M. J., Lai, H. and Turner, S. R. (2012) 'assessment Using automatic item generation to create multiple- choice 
test items', pp. 757-765. doi: 10.1111/j.1365-2923.2012.04289.x.

Hill, H. C. et al. (2011) 'Teacher ValueAdded Scores'. doi: 10.3102/0002831210387916.

Oche, E. S. (2012) 'Assessing the Relative Effectiveness of Three Teaching Methods in the Measurement of Student Achievement in Mathematics', 3(4), pp. 479-486.

Odukoya, J. A. et al. (2018) 'Item analysis of university-wide multiple choice objective examinations : the experience of a Nigerian private', Quality \& Quantity. Springer Netherlands, 52(3), pp. 983-997. doi: 10.1007/s11135017-0499-2.

Pugh, D. et al. (2016) 'Using cognitive models to develop quality multiplechoice questions', 38(8), pp. 838-843.

Suranto, Muhyadi and Mardapi, D. (2014) 'Pengembangan instrumen evaluasi uji kompetensi keahlian (ukk) administrasi perkantoran di smk', pendidikan dan evaluasi pendidikan, 18(1).

Suyata, P., Mardapi, D. and Kartowagiran, B. (2010) 'Identifikasi Need Assessment ':, 40, pp. 45-58.

Wiliam, D. et al. (2010) 'Teachers developing assessment for learning: impact on student achievement Teachers developing assessment for learning: impact on student achievement'. doi: 10.1080/0969594042000208994.

Yew, T. M., Dawood, F. K. P. and Narayansany, S. (2015) 'Designing an Instrument for Providing Better Student Feedback on Teaching Effectiveness', 3(1), pp. 14-22.

Zamsir (2012) 'Kualitas tes buatan guru pada mata pelajaran matematika di sd negeri kota kendari', 1(01), pp. 49-65.

\section{Article Metadata:}

Nengsi, A.R. Efrina, G. (2019). Optimization of Teacher-Made Achievement Tests of Elementary School Social Science Subject for Precise Learning Evaluation. Ta'dib, 22 (2), 121-130.

http://dx.doi.org/10.31958/jt.v22i2.1498

Keywords: Optimalization, Teacher-Made Achievement Tests, Item Characteristics Analysis

Coresponding author: Ayu Rahma Nengsi, STAIN Gajah Putih Takengon Aceh, rahmanengsiayu@gmail.com 